Original Research Paper

\title{
Peningkataan Produktivitas Keramba Jaring Apung dengan Budidaya Kerang Mutiara Sistem Terintegrasi di Kabupaten Lombok Utara
}

\author{
Muhammad Junaidi $^{1^{*}}$, Nunik Cokrowati ${ }^{1}$, Nanda Diniarti ${ }^{1}$ \\ 1 Jurusan Perikanan dan Ilmu Kelautan Fakultas Pertanian Universitas Mataram \\ Jl. Majapahit No. 62 Mataram, Nusa Tenggara Barat
}

DOI: https://doi.org/10.29303/jpmpi.v4i2.696

Sitasi: Junaidi, M., Cokrowati, N., \& Diniarti, N. (2021). Peningkataan Produktivitas Keramba Jaring Apung dengan Budidaya Kerang Mutiara Sistem Terintegrasi di Kabupaten Lombok Utara. Jurnal Pengabdian Magister Pendidikan $I P A, 4(2)$

\section{Article history}

Received: 03 Februari 2021

Revised: 08 Maret 2021

Accepted: 10 April 2021

*Corresponding Author:

Muhammad Junaidi, Jurusan

Perikanan dan Ilmu

Kelautan Fakultas Pertanian

Universitas Mataram

Email: m.junaidi@unram.ac.id.

\begin{abstract}
Kegiatan pengabdian kepada masyarakat (PkM) budidaya $\mathrm{n}$ kerang mutiara secara terintegrasi dengan tujuan untuk meningkatkan produktivitas keramba jaring melalui penerapan dan pengembangan teknologi budidaya terintegrasi. Metode pelaksanaan PkM ini adalah metode transfer teknologi, dengan langkah-langkah yang telah disepakati bersama antara lain sosialisasi kegiatan PkM, pelatihan, demonstrasi plot (demplot) budidaya kerang mutiara sistem terintegrasi dan pendampingan. Hasil kegiatan $\mathrm{PkM}$ memberikan nilai posisif bagi masyarakat sasaran, dengan budidaya kerang mutiara sistem terintegrasi produksi keramba jaring apung tidak lagi mengandalkan pada satu komoditas, akan tetapi satu unit KJA dapat menghasilkan lebih dari satu komoditas yaitu lobster dan kerang mutiara. Dengan demikian. diharapkan kegiatan ini terus dilanjutkan dan diperluas, sehingga tujuan dan manfaat program dapat tercapai dan berkontribusi pada peningkatan kualitas hidup dan pendapatan masayarakat
\end{abstract}

Keywords: kerang mutiara, budidaya laut terintegrasi, pelatihan, demplot

\section{Pendahuluan}

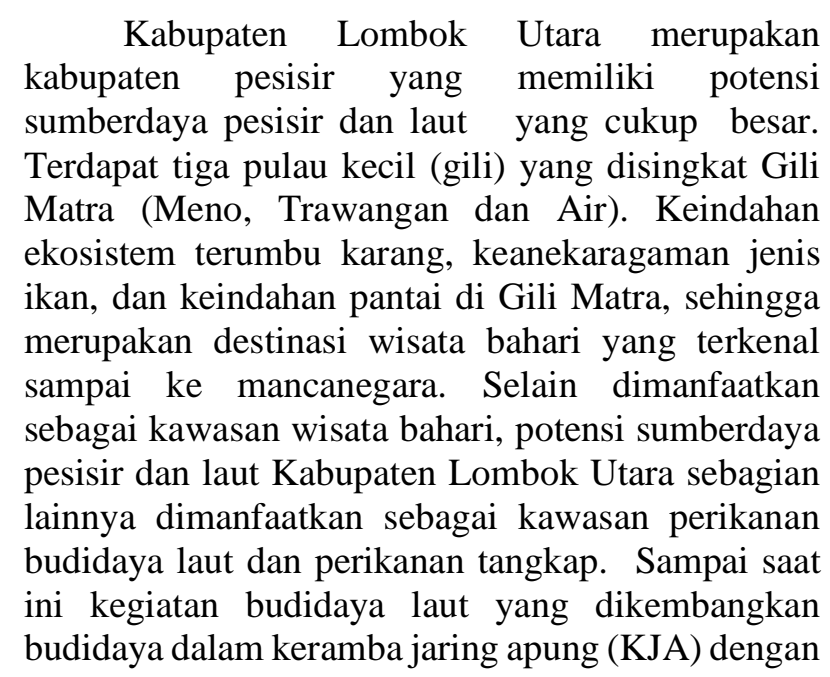

komoditas kerapu dan lobster, serta kerang mutiara mutiara (Junaidi et al., 2018a; Junaidi et al., 2018b). Usaha budidaya ikan kerapu dan bawal dalam KJA masih dalam skala kecil, dimana Kelompok Pembudidaya Ikan (Pokdakan) Mekar Bahari di Desa Jenggala Kecamatan Tanjung merupakan salah satu kelompok masyarakat yang mengusahakan budidaya dalam KJA (Junaidi et al., 2020). Sementara usaha budidaya kerang mutiara telah berkembang dalam skala industri sejak tahun 1980-an, yang dikelola perusahaan bahkan salah satu perusahaan mutiara terbesar di dunia berlokasi di perairan Kabupaten Lombok Utara.

Di Kabupaten Lombok Utara potensi pengembangan pembesaran bibit kerang mutiara sangat mendukung, dimana hasil produksi dari bibit kerang mutiara berkualitas baik sehingga menjadikan kawasan ini sebagai pilihan 
pengembangan budidaya (Hadinata et al., 2019). Pemanfaatan wilayah pesisir untuk pengembangan budidaya kerang mutiara di Lombok Utara harus dilaksanakan secara berkelanjutan dengan melibatkan masyarakat pesisir. Keterlibatan masyarakat sekitar akan berimbas pada peningkatan kesejahteraan masyarakat dan pada akhirnya keberlanjutan usaha budidaya mutiara menjadi lebih terjamin. Salah satu upaya untuk mendorong keterlibatan masyarakat pesisir adalah melalui sigmentasi usaha, sehingga perusahaan tidak bersifat exclusive, tetapi bersifat terbuka, bekerjsama dengan masyarakat sekitar yang saling menguntungkan. Bentuk kerjasamanya dengan mendorong masyarakat melakukan usaha budidaya kerang mutiara dari benih sampai ukuran $7 \mathrm{~cm}$, dan selanjutnya dikelola oleh perusahaaan dengan operasi penyisipan inti sampai panen (Syachruddin et al., 2018).

Kelompok Pembudidaya Ikan (Pokdakan) Mekar Bahari Desa Jenggala Kecamatan Tanjung Kabupaten Lombok Utara. Kelompok masyarakat pembudidaya ikan ini berdiri sejak tahun 2018 dan jenis usaha budidaya laut. Pada awal tahun 2019 pemerintah memberikan bantuan sarana KJA, namun pada kenyataannya tingkat produktivitas dan pemanfaatan KJA belum optimal. Selama ini pemamfaatan KJA dengan sistem monokultur atau satu species saja, yaitu ikan kerapu atau lobster. Padahal sarana KJA, selain dapat dimanfaatkan sebagai sarana budidaya ikan atau udang dalam jaring arung, KJA dapat juga digunakan untuk budidaya kerang mutiara yaitu sebagai tempat menggantung keranjang-keranjang jaring (pocket). Praktik budidaya perikanan dengan lebih dari satu species diyakini mampu meningkatkan kapasitas produksi KJA. Menurut Imam \& Putro (2019), salah satu solusi yang tepat menuju praktik budidaya produktif dan berkelanjutan adalah penerapan KJA dengan metode terintegrasi (integrated multi-trophic aquaculture). Budidaya dengan metode terintegrasi merupakan inovasi pengembangan sistem perikanan budidaya, jika dibandingkan dengan perikanan budidaya konvensional hanya menggunakaan satu komoditas budidaya saja. Budidaya terintegrasi ini memadukan beberapa komoditas yang memiliki tingkat tropik yang berbeda antara komoditas yang diberi pakan (misalnya ikan dan udang) dengan komoditas penyerap bahan anorganik (misalnya rumput laut), dan komoditas penyerap bahan organik (suspension dan deposit feeder, seperti kekerangan)
(Radiarta \& Erlania, 2016; Radiarta et al., 2014; Troell et al., 1997).

Berdasarkan uraian di atas, maka dilaksanakan kegiatan PkM budidaya kerang mutiara secara terintegrasi dengan tujuan untuk meningkatkan produktivitas keramba jaring apung, sehingga diharapkan adanya peningkatan pengetahuan dan keterampilan dalam kegiatan usaha ekonomi produktif dan usaha kesejahteraan sosial kelompok masyarakat sasaran.

\section{Metode}

\section{Khalayak Sasaran}

Khalayak sasaran Pengabdian kepada Masyarakat $(\mathrm{PkM})$ peningkatan produktivitas keramba jaring apung adalah Kelompok Pembudidaya Ikan (Pokdakan) Mekar Bahari. Pokdakan Mekar Bahari terletak di Dusun Penyambuan Desa Jenggala Kecamatan Tanjung Kabupaten Lombok Utara Provinsi Nusa Tenggara Barat (Gambar 1). Kegiatan PkM dilaksanakan pada bulan Mei sampai November 2019.

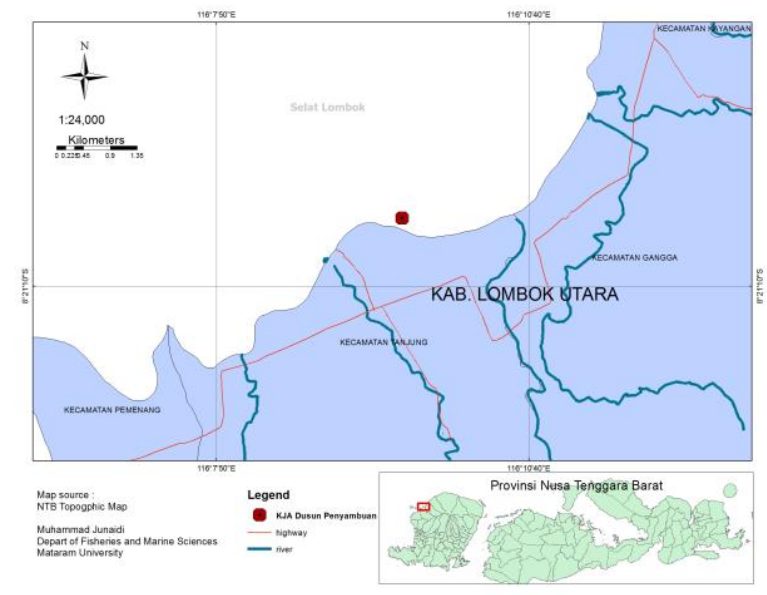

Gambar 1. Lokasi pengabdian kepada massyarakat

\section{Bahan dan Alat}

Rancangan kegiatan dalam memberikan solusi untuk peningkatan produktivitas keramba jaring apung Pokdakan Mekar Bahari dengan menggunakan metode pelatihan dan produksi demonstrasi plot (demplot) budidaya kerang mutiara sistem terintegrasi. Demplot pemeliharaan kerang dilakukan pada keranjang-keranjang jaring (pocket), dengan cara digantung pada kerangka keramba jaring apung (KJA) (Gambar 2). Bahan rangka yang digunakan untuk pocket terbuat dari 
kawat galvanizer, dan pocket dilengkapi dengan jaring dengan mess size $0,5 \mathrm{~cm}$. Ukuran pocket 0.4 x $0.6 \mathrm{~m}$ yang diisi sebanyak 24 ekor spat (benih kerang mutiara) dengan panjang dorval 29,6 - 30,3 $\mathrm{mm}$.

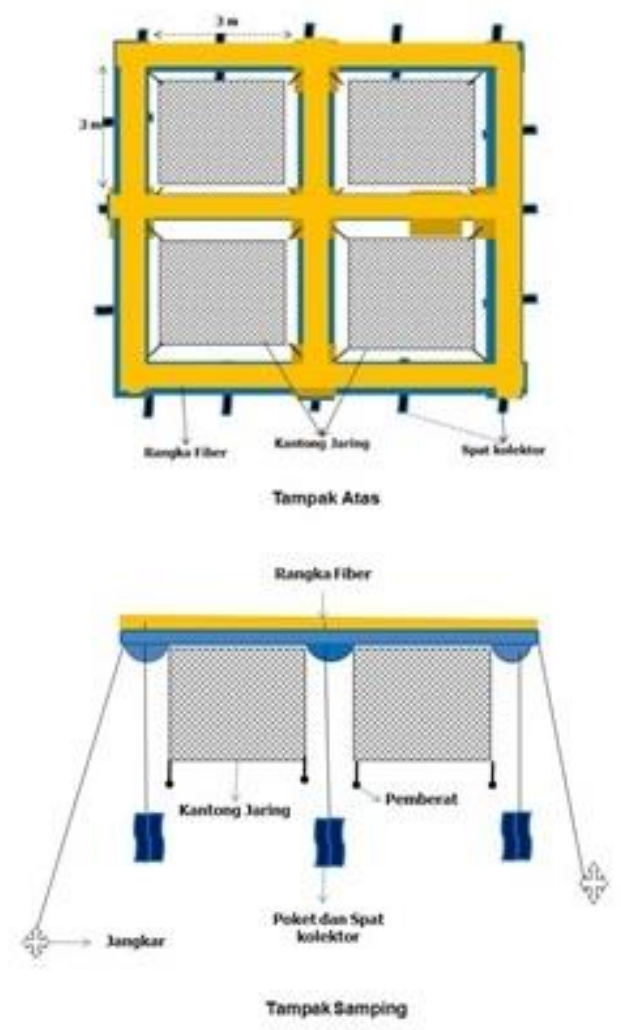

Gambar 2. Rancangan demplot budidaya kerang mutiara

\section{Metode dan Prosedur Pelaksanaan}

Metode pelaksanaan PkM adalah metode pelatihan produksi dan demonstrasi plot (demplot), dengan prosedur pelaksanaan untuk mendukung realisasi kegiatan PkM dengan langkah-langkah yang telah disepakati bersama antara lain sosialisasi kegiatan PkM, pelatihan, demonstrasi plot (demplot) budidaya kerang mutiara sistem terintegrasi dan pendampingan (Gambar 3).

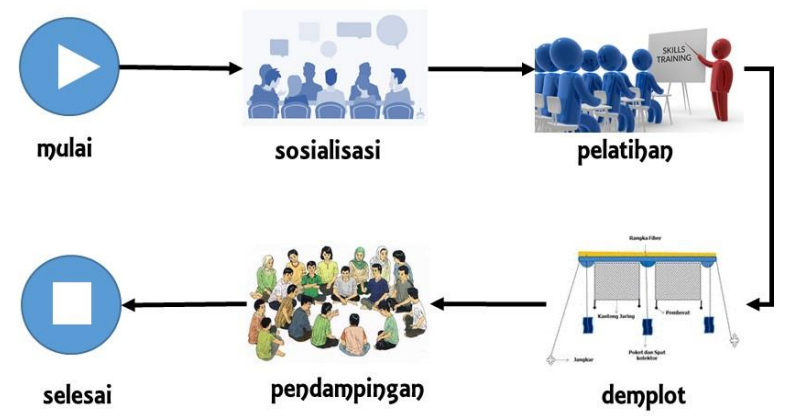

Gambar 3. Prosedur pelaksanaan PkM

1. Sosialisasi. Kegiatan sosialisasi dimaksudkan untuk meningkatkan kualitas pelaksanaan PkM ini,dan untuk menyamakan persepsi dengan para stakeholder, dengan harapan untuk mendapatkan respons yang baik sehingga kegiatan PkM ini dapat berjalan dengan baik dan lancar. Selain dihadiri pengurus dan anggota Pokdakan Mekar Bahari, kegiatan sosialisasi juga dihadari dinas dan instansi terkait, yaitu Pemerintah Daerah Kabupaten Lombok Utara, Kecamatan Tanung dan Desa Jenggala. Menurut Herdiana (2018) sosialisasi sebagai upaya memasyarakatkan suatu kebijakan yang telah dihasilkan perlu diketahui oleh masyarakat sehingga kebijakan tersebut selain dapat terlaksana dengan baik juga mendapatkan dukungan dari masyarakat.

2. Pelatihan. Untuk meningkatan pengetahuan, keterampilan, teknologi dan manajemen dalam pengelolaan usaha budidaya laut sistem IMTA, maka dilakukan pelatihan. Pelatihan peserta didik merupakan salah bentuk pendidikan orang dewasa, dimana menurut Sunhaji (2013) pendidikan orang dewasa adalah kegiatan membimbing dan membantu orang dewasa belajar, merupakan suatu proses penemuan (pengetahuan, keterampilan, dan sikap) sepanjang hayat terhadap sesuatu yang dibutuhkan dan diperlukan untuk kehidupanya, prosesnya tidak di dasarkan pada pertimbangan pendidik, akan tetapi di dasarkan pada kepentingan peserta didik.

3. Demonstrasi Plot (demplot). Demplot budidaya kerang mutiara dilakukan pada keranjangkeranjang jaring (pocket) sebanyak 16 unit, dengan cara digantung pada 4 unit petak KJA. Kegiatan demplot diawali dengan pengadadaan bahan dan alat serta benih kerang mutiara (spat), penebaran dan pemeliharaan selama empat 
bulan. Berdasarkan hasil penelitian diperoleh bahwa pemeliharaan kerang mutiara selama 4 bulan diharapkan kerang akan tumbuh dengan panjang cangkang 40-50 $\mathrm{mm}$ (Hamzah \& Nababan, 2009).

4. Pendampingan. Pendampingan dilakukan dengan tujuan untuk membantu memecahkan masalah-masalah yang terjadi dalam menjalankan usaha budidaya kerang mutiara. Pendamping sebagai agen perubahan yang turut terlibat membantu memecahkan persoalan yag dihadapi kelompok masyarakat (Nugraha, 2009), dimana Tim PkM dan seorang Mahasiswa yang kebetulan sedang penelitian skripsi di KJA milik Pokdakan Mekar Bahari, baik masalah teknis usaha maupun masalah manajemen kelompok. Selama pendampingan dilakukan evaluasi kegiatan untuk mengetahui tingkat pertumbuhan kerang mutiara.

\section{Analisis Data}

Untuk mengetahui keberhasilan PkM budidaya kerang mutiara (Pinctada maxima) secara terintegrasi, maka dilakukan pengumpulan data pertumbuhan biota yang dipelihara. Pengumpulan data dilakukan setiap bulan sekali dengan melakukan sampling terhadap biota yang dipelihara pada setiap pocket. Pengamatan pertumbuhan spat kerang mutiara dengan pertumbuhan panjang antero-posterior (AP). Parameter yang diamati adalah pertumbuhan pertumbuhan panjang (length growth = LG), laju pertumbuhan spesifik (specific growth rate $=$ SGR) dan kelangsungan hidup (survival rate $=\mathrm{SR}$ ) mengacu pada (Hamzah \& Nababan, 2009; Junaidi et al, 2019; Oktaviani et al., 2018; Winanto et al., 2016) dengan persaman sebagai berikut :

- Pertumbuhan panjang $(\mathrm{LG}=\%)$ :

$$
L G(\%)=100 \times \frac{\text { panjang akhir - panjang awal }}{\text { panjang awal }}
$$

- Laju pertumbuhan spesifik (SGR $=\% /$ hari) :

$$
S G R=100 x \frac{L N \text { panjang akhir }-L N \text { panjang awal }}{\text { lama pemeliharaan }}
$$

- Kelangsungan hidup (SR =\%) :

$$
S R=100 \times \frac{\text { jumlah biota akhir }}{\text { jumlah biota awal }}
$$

\section{Hasil dan Pembahasan}

Kegiatan sosialisasi PkM dilaksanakan pada hari Kamis tanggal 1 Agustus 2019 pukul 10.00 Wita bertempat di Rumah Jaga KJA milik
Pokdakan Mekar Bahari. Kegiatan sosialisasi dihadiri 20 peserta yang terdiri dari Kepala Bidang Perikanan Budidaya dan Kepala Bidang Perikanan Tangkap Dinas Perhubungan dan Kelautan Kabupaten Lombok Utara, Penyuluh Perikanan, Babinsa, Bhayankantimas, Kepala Desa Jenggala, anggota dan pengurus Kelompok Mekar Bahari dan pendamping mahasiswa (Gambar 4). Keterlibatan berbagai pihak dalam sosialisasi tentunya akan dampak positif bagi keberhasilan program ini, dimana menurut Herdiana (2018) berbagai pihak yang terlibat akan memiliki sikap dan tindakan berupa kesadaran dan rasa tanggungjawab untuk menyukseskan implementasi kebijakan yang telah dibuat sesuai dengan perannya masing-masing. Berdasarkan diskusi yang berlangsung selama sosialisasi, pihak Pemda Kabupaten Lombok Utara melalui Kepala Bidang Bidang Perikanan Budidaya sangat mendukung program ini, bahkan bersedia memberikan bantuan berupa 1 unit KJA dan bibit ikan kerapu sebanyak 100 ekor pada Pokdakan Mekar Bahari.
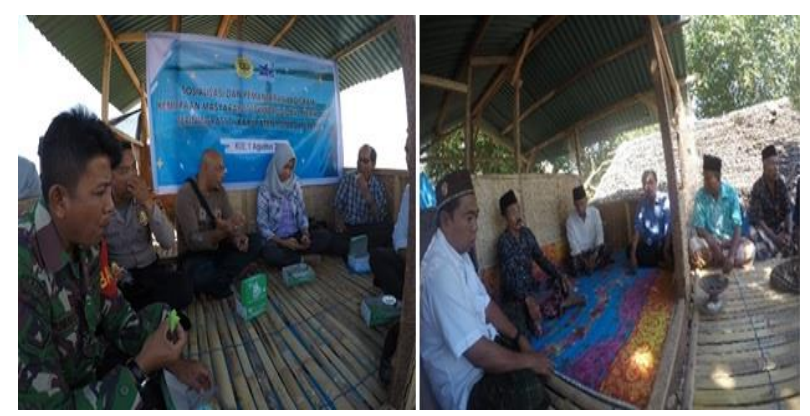

Gambar 4. Pelaksanaan sosialisasi PkM

Untuk meningkatan pengetahuan, keterampilan, teknologi dan manajemen dalam pengelolaan usaha budidaya laut sistem IMTA, maka dilakukan pelatihan. Pelatihan peserta didik merupakan salah bentuk pendidikan orang dewasa, dimana menurut Sunhaji (2013) pendidikan orang dewasa adalah kegiatan membimbing dan membantu orang dewasa belajar, merupakan suatu proses penemuan (pengetahuan, keterampilan, dan sikap) sepanjang hayat terhadap sesuatu yang dibutuhkan dan diperlukan untuk kehidupanya, prosesnya tidak di dasarkan pada pertimbangan pendidik, akan tetapi di dasarkan pada kepentingan peserta didik. Pelatihan dilaksanakan pada hari Sabtu, tanggal 19 Oktober 2019 dengan cara pembagian brosur dan bahan 
bacaan. Adapun materi dalam brosur dan bahan bacaan yang diberikan adalah teknik budidaya kerang mutiara dengan sistem terintegrasi. Untuk meningkatkan keterampilan tentang budidaya kerang mutiara mereka secara bergiliran bersama pendamping lapangan melakukan kegiatan yang terkait dengan budidaya kerang mutiara. Misalnya, pembersihan pocket kerang mutiara (Gambar 5). Metode peningkatan keterampilan tersebut, diharapkan adanya transfer ilmu pengetahuan dan teknologi kepada peserta didik.
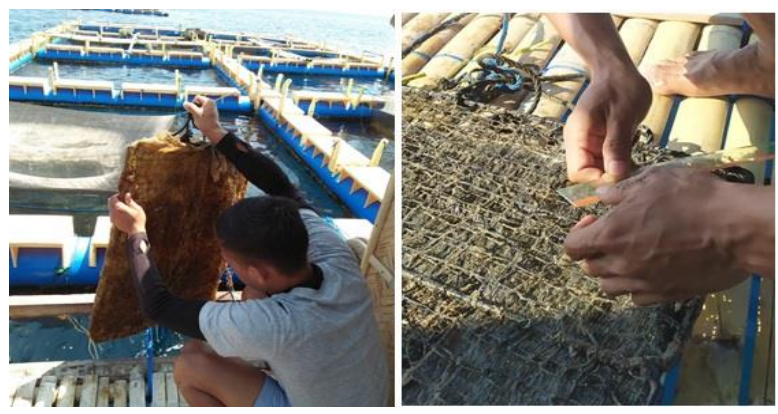

Gambar 5. Membersihan pocket spat kerang

Pada pelaksanaan demonstrasi plot (demplot), diawali dengan persiapan keranjangkeranjang jaring (pocket) yang terbuat dari bahan kawat galvanizer sebanyak 16 unit (Gambar 6). Selain itu juga disiapkan satu bangunan yaitu rumah jaga dengan ukuran $5 \times 5 \mathrm{~m}$ yang berbuat dari kayu dan bambu dan pelampung dari drumpon sebanyak 9 buah (Gambar 7). Rumah jaga ini ditempatkan disamping KJA, selain berfungsi rumah jaga, bangunan ini juga berfungsi sebagai gudang dan balai pertemuan anggota Pokdakan Mekar Bahari.
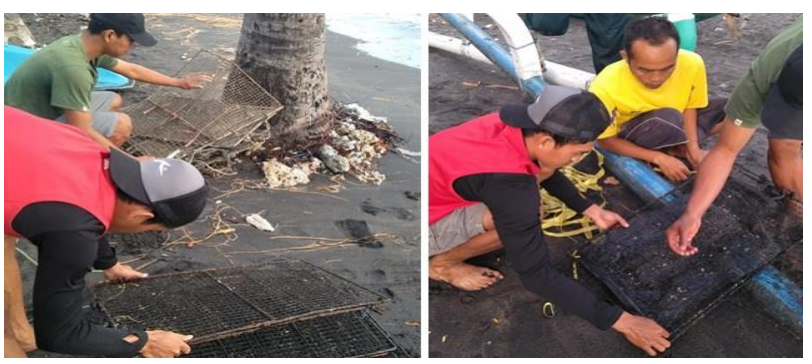

Gambar 6 Persiapan pocket spat kerang

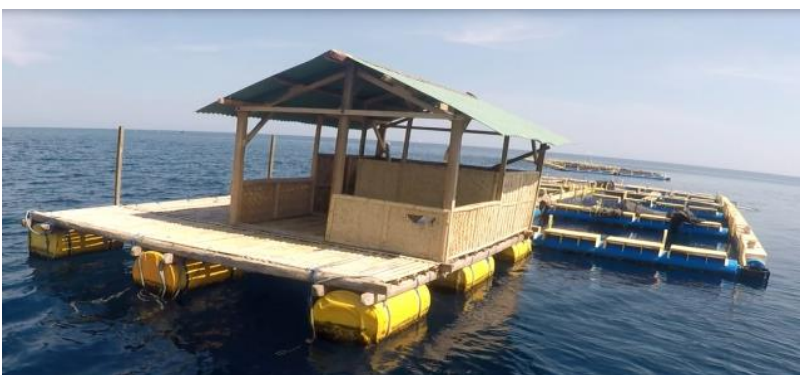

Gambar 7. Rumah jaga KJA

Benih (spat) kerang mutiara diperoleh dari Balai Perikanan Budidaya Laut (BPBL) Sekotong Kabupaten Lombok Barat. Benih kerang mutiara ini merupakan hasil produksi dari panti benih (hatchery) sehingga relatif mudah diperoleh dan ketersediaannya realtif banyak. Benih kerang mutiara ini menempel pada jaring atau disebut kolektor (Gambar 8). Penebaran benih kerang mutiara dilakukan pada tanggal 16 Agustus 2019 pada 16 unit pocket sebanyak 24 ekor spst per pocket dengan ukuran 29,6-30,3 $\mathrm{mm}$.
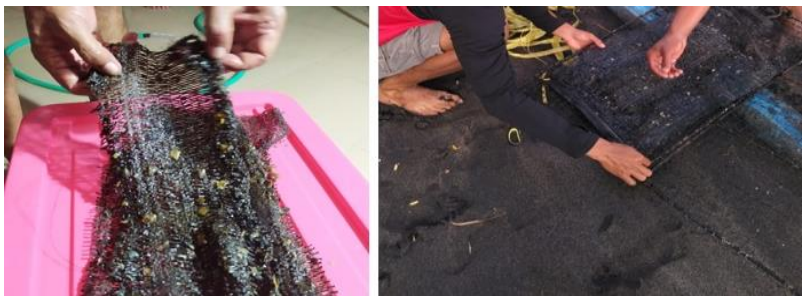

Gambar 8. Penebaran spat kerang mutiara

Pada kegiatan pendampingan, Pokdakan Mekar Bahari yang memiliki anggota 10 orang oleh Tim PkM dan seorang mahasiswa yang sedang melakukan penelitian di KJA milik kelompok. Melalui pendampingan diharapkan masyarakat pesisir bisa lebih mandiri dalam mengembangkan usaha budidaya kerang mutiara yang terintegrasi dengan budidaya lobster. Selain itu, dengan pendampingan dapat menambah pendapatan keluarga, karena mereka mendapat pengetahuan dan keterampilan dalam manajemen kewirausahaan. Selama pendampingan dilakukan pengukuran pertumbuhan panjang spat kerang mutiara dan kelangsungan hidup setiap bulan dimulai pada bulan Agustus sampai dengan November 2019 (Gambar 9, 10 dan 11). 


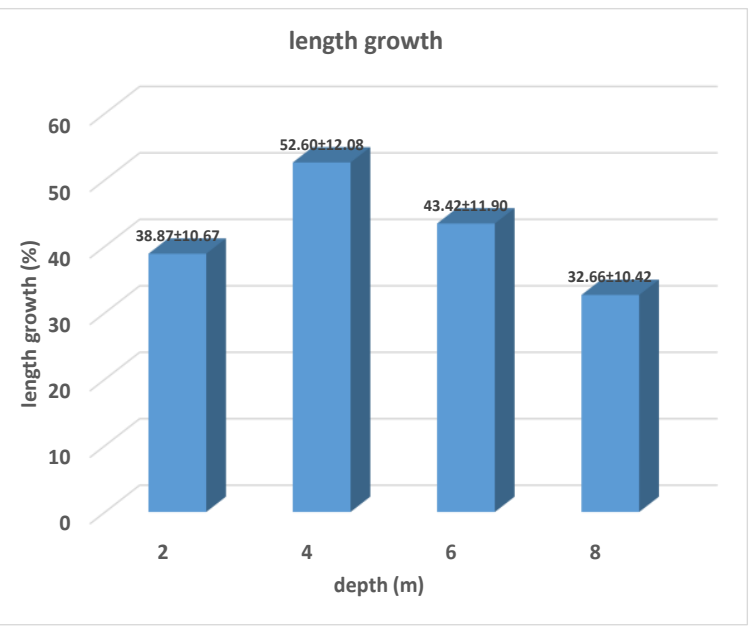

Gambar 9. Pertumbuhan panjang cangkang kerang mutiara

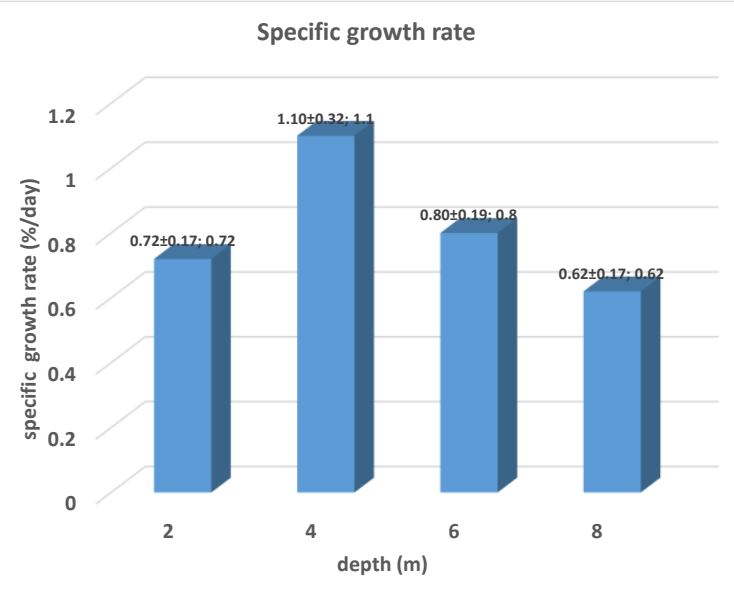

Gambar 10. Laju pertumbuhan spesifik kerang mutiara

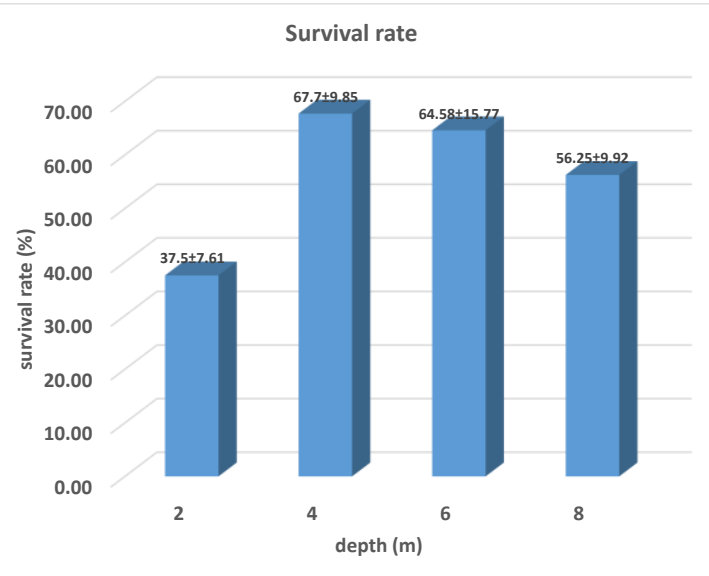

Gambar 11. Kelangsungan hidup kerang mutiara
Hasil pengamatan panjang cangkang kerang mutiara pada bulan Agustus berkisar antara 29,65 - 30,33 mm, dan panjang akhir pada bulan November berkisar antara 40,20 - 49,00 mm, sehingga diperoleh pertumbuhan panjang (length growth) selama 4 bulan pemeliharaan berkisar antara $32,66-52,60 \%$, dan laju pertumbuhan spesifik (specific growth rate) berkisar antara 0,17 - 0,32 \%/hari dan kelangsungan hidup (survival rate) berkisar antara $37,50-67,70 \%$. Performa pertumbuhan dan kelangsungan hidup kerang mutiara pada kegiatan demplot ini tidak jauh berbeda dengan hasil penelitian sebelumnya (Hamzah \& Nababan, 2009; Junaidi et al, 2019; Oktaviani et al., 2018; Winanto et al., 2016). Berdasarkan kegiatan demplot budidaya kerang mutiara selama 4 bulan dengan pocket 16 unit diperoleh sebanyak 217 ekor kerang mutiara dengan ukuran 4,0-4,9 cm. Hal ini menunjukkan pertumbuhan dan kelangsungan hidup kerang mutiara cukup bagus serta tingginya animo masyarakat khususnya Pokdakan Mekar Bahari dan dukungan pemerintah daerah dalam kegiatan PkM ini. Diharapkan dengan selesainya kegiatan pelaksanaan PkM ini keberlanjutan program terus dilakukan bahkan diperluas, sehingga tujuan dan manfaat program dapat tercapai dan berkontribusi pada peningkatan kualitas hidup dan pendapatan masyarakat

\section{Kesimpulan}

Kegiatan PkM budidaya kerang mutiara (Pinctada maxima) dapat meningkatkan produkvititas keramba jaring apung, dengan pertumbuhan panjang cangkang berkisar antara 32,66 - 52,60 \%, laju pertumbuhan spesifik berkisar antara $0,17-0,32 \%$ /hari dan kelangsungan hidup berkisar antara 37,50-67,70\%. Selain itu, budidaya kerang mutiara dengan sistem terintegrasi dapat menghasilkan dua komoditas sekaligus yaitu lobster (Panulirus homarus) dan kerang mutiara.

\section{Saran}

Kegiatan pengabdian kepada masyarakat mampu meningkatkan produktivitas usaha budidaya laut, maka diharapkan kegiatan ini terus dilanjutkan dan diperluas, sehingga tujuan dan 
manfaat program dapat tercapai dan berkontribusi pada peningkatan kualitas hidup dan pendapatan masayarakat

\section{Ucapan Terima Kasih}

Ucapan terima kasih disampaikan kepada Kementerian Riset, Teknologi dan Pendidikan Tinggi (Kemenristekdikti) yang telah mendanai kegiatan Progran Kemitraan Masyarakat, Lembaga Penelitian dan Pengabdian kepada Masyarakat (LPPM) Universitas Mataram, Pemerintah Desa Jenggala, Bidang Perikanan Budidaya Dinas Perhubungan dan Kelautan Kabupaten Lombok Utara, dan Pokdakan Mekar Bahari yang telah mendukung dan mensukseskan program ini.

\section{Daftar Pustaka}

Dian Herdiana. (2018). Sosialisasi Kebijakan Publik: Pengertian dan Konsep Dasar. Jurnal Ilmiah Wawasan Insan Akademik, 1(3), 13-26. Retrieved from https://scholar.google.co.id/scholar?cluster $=6$ 261633184899254674\&hl=en\&as_sdt=2005

Hadinata, F. W., Yulainda, F., \& Yonvitner. (2019). Studi kesesuaian kawasan budidaya kerang mutiara di Pesisir Kabupaten Lombok Utara. Journal of Aceh Aquatic Science, 3(1), 39-57. https://doi.org/https://doi.org/10.35308/.v3i1.1 712

Hamzah, M.S., \& Nababan, B. (2009). Studi pertumbuhan dan kelangsungan hidup anakan kerang mutiara (Pinctada maxima) pada kedalaman berbeda di teluk Kapontori, Pulau Buton. E-Jurnal Ilmu Dan Teknologi Kelautan Tropis, 1(2), 22-32. Retrieved from https://repository.ipb.ac.id/bitstream/handle/1 23456789/53384/e_jurnal_2_1_3.pdf?sequenc $\mathrm{e}=1 \&$ isAllowed $=\mathrm{y}$

Hamzah, Mat Sardi, \& Nababan, B. (2009). The growth and survival study of pearl oyster seeds (Pinctada maxima) based on the difference depth levels in Kapontori Bay, Buton Island. $J$. Ilmu Dan Tek Kelautan Tropis, 1(2), 22-32.

Imam, T., \& Putro, S. P. (2019). Pengembangan Budidaya Perikanan Produktif Berkelanjutan Sistem IMTA (Integrated Multi-Trophic
Aquaculture) (Studi Kasus di Kep. Karimunjawa, Jepara). Life Science, 8(2), 192199.

Junaidi, M., Ahmad, Z., \& Astriana, B. H. (2019). Pengaruh Kepadatan Spat Kerang Mutiara (Pinctada Maxima) Dengan Metode Longline Terhadap Pertumbuhan Dan Kelangsungan Hidup. Jurnal Biologi Tropis, 19(2), 221. https://doi.org/10.29303/jbt.v19i2.1273

Junaidi, M., Lestary, D. P., \& Scabra, A. R. (2018). Mariculture Site Selection Based on Environmental Parameters in Tanjung and Gangga Sub-District, North Lombok. Proceedings The Ist Internatioal Confrences and Workshop on Bioscience and Prosperity, (November), 233-251.

Junaidi, M., Nurliah, \& Azhar, F. (2018). Conditions of Water Quality to Support Lobster Cultivation in North Lombok Regency, West Nusa Tenggara Province. J. Sains Teknologi \& Lingkungan, 4(2), 108-119.

Junaidi, M., Setyono, B. D. H., \& Azhar, F. (2020). Demplot Budi Daya Lobster dan Kerang Mutiara secara Terintegrasi dalam Rangka Penguatan Kemitraan Masyarakat Lombok Utara. Agrokreatif Jurnal Ilmi Pengabdian Kepada Masyarakat, 6(3), 249-259. https://doi.org/https://doi.org/10.29244/agrokr eatif.6.3.249-259

Nugraha, A. (2009). Pengembangan Masyarakat Pembangunan Melalui Pendampingan Sosial Dalam Konsep Pemberdayaan Di Bidang Ekonomi. Jurnal Ekonomi Modernisasi, 5, 10. Retrieved from http://ejournal.ukanjuruhan.ac.id

Oktaviani, T., Cokrowati, N., \& Astriana, B. H. (2018). The survival rate of pearl shell spat with differnet densities at the Marine Aquaculure Center Lombok. Jurnal Kelautan, $11(1)$, 47-55. https://doi.org/10.21107/jk.v11i1.3136

Radiarta, I. N., \& Erlania. (2016). Performa komoditas budidaya laut pada sistem integrated multi-trophic aquaculture (IMTA) di Teluk Gerupuk, Lombok Tengah, Nusa Tenggara Barat. J. Ris Akuakultur, 11(1), 8597. 
Radiarta, I. N., Erlania, \& Sugama, K. (2014). Budidaya rumput laut, Kappaphycus alvarezii secara terintegrasi dengan ikan kerapu di Teluk Gerupuk Kabupaten Lombok Tengah, Nusa Tenggara Barat. J. Ris Akuakultur, 9(1), 125134.

Sunhaji. (2013). Konsep pendidikan orang dewasa. J. Kependidikan, 1(1), 1-11.

Syachruddin, A., Syukur, A., \& Suryaningsih, S. (2018). Perbedaan berat (gram) bibit kerang mutiara (Pinctada Maxima) antar warna cangkang di perairan Tekalok Lombok Timur NTB. J. Biologi Tropis, 18(1), 34-44. https://doi.org/10.29303/jbt.v18i1.553

Troell, M., Halling, C., Nilsson, A., Buschmann, A. H., Kautsky, N., \& Kautsky, L. (1997). Integrated marine cultivation of Gracilaria chilensis ( Gracilariales , Rhodophyta ) and salmon cages for reduced environmental impact and increased economic output. Aquaculture, 156, 45-61.

Winanto, T., Marasabessy, M. D., \& Dody, S. (2016). Kepadatan Optimum dan Morfologi Spat Tiram Mutiara Pinctada maxima (Jameson) pada Pemeliharaan dengan Tingkat Kepadatan Berbeda. OMNI Akuatika, 12(3), 138-143. 